\title{
From Africa and India to Blackpool: Military history and ambulance services
}

W de Villiers, Knight of the Most Venerable Order of Saint John, London, United Kingdom; and President of the Cape of Good Hope District of St John Ambulance, Cape Town, South Africa

peccator@hotmail.com

Those who get to know Peter Beighton cannot fail to be aware that he is a man of many and varied interests, not the least among them being genealogy, geography and local history.

One of his more surprising accomplishments is that he is the recognised world authority on the Medal for the South African War (1899 - 1902) issued by the Order of St John.

How that came to be is a not uninteresting story.

\section{Arrival in South Africa}

Peter came to South Africa not long after his marriage to Greta in 1970. They moved into an apartment, which seemed 'palatial' to them, and in which - as newcomers both to the country and to domesticity - they spent much time.

In the evenings, Peter occupied himself with Greta's childhood collection of postage stamps, enjoying the links between these simple pieces of paper and the worlds of geography and history.

The medical research project on which Peter was working required him to travel around the country. On occasion he found himself in Mafeking (Mahikeng), a place of considerable significance to British children of his generation - the site of a 217-day siege during the South African War, which turned the British soldier Robert Baden Powell into a hero and helped him on his way to founding the Scouting movement.

Aware that a medal had been issued to the defenders of Mafeking, Peter thought it might make an interesting reminder of, and link to, a dramatic episode in South African history. And by a satisfying coincidence, shortly afterwards he met the well-known Cape Town medal collector and University of Cape Town administrator, Bill Hibbard, who agreed to sell him a Queen's South Africa Medal with the bar, 'Defence of Mafeking.'

Henceforth, Peter was to be not only a stamp collector, but also a keen and knowledgeable collector of medals.

\section{Medal collecting}

Collecting orders, medals and decorations is an aspect of the discipline sometimes referred to as 'phaleristics', a word, we are told, coined by the Czech collector Oldrich Pitz in 1937, derived from the Latin expression phalerae, used by the Romans for the discs, made of bronze, silver or gold, attached to the breastplates of distinguished soldiers.

This is a wide and sometimes turbulent sea. The limits of the discipline are contested and the word phaleristics itself, though current in Europe, is not much used in English-speaking circles.

A useful working definition, however would be the study, classification and cataloguing of insignia worn on the body, which are given for services rendered, or for individual or collective merits, or as badges of membership or office. ${ }^{[1-3]}$

The value of this definition is that it underlines the fact that phaleristics concentrates not on the glory of war (a common misconception about medal collecting and medal collectors), but on the study of artefacts given to indicate honour or respect - artefacts which have a historical and social context worthy of research.
In this regard it is interesting to note that Peter Beighton's books, Blackpool Division, St John Ambulance Brigade: The Early Years (1998) and The Royal Naval Reserve Long Service and Good Conduct Medal as awarded to the Royal Naval Auxiliary Sick Berth Reserve (2004), refer respectively to awards made by a voluntary ambulance organisation and awards made for long service by volunteer naval sick berth attendants. ${ }^{[4,5]}$

\section{Changing times and interests}

At first, Peter collected campaign medals illustrative of the many wars and military expeditions that punctuate the history of Britain's imperial past.

The then-current reference work on the subject was the 4th edition of British Battles and Medals (Major LL Gordon, 1971), which regarded the earliest British campaign medals, 'the first issued for service against a foreign foe', to be the Elizabethan Naval Medals distributed to commemorate the defeat of the Spanish Armada in 1588. ${ }^{[6]}$

The first medal awarded by the British government to all soldiers engaged in a campaign, without exception and without distinction as to rank, the first medal awarded to the next-of-kin of those who were killed during the campaign, and the first campaign medal to bear the recipient's name and unit officially impressed around the edge, was the Waterloo Medal of 1815.

These innovations set standards that have been adhered to by the authorities ever since. For collectors such as Peter Beighton, they have additional significance. Because Waterloo Medals were awarded to all the soldiers present on operations, or their next-of-kin, they were issued - and have survived - in sufficient quantities to make collection relatively easy. Secondly, because they were officially impressed with the recipients' details, they enable collectors to research not merely the campaign, but also the role of the various units present, and the biography of individual recipients.

As time went on, Peter made several visits to India. He was fortunate to do so when there was still very little interest in the sub-continent in the medals of the British Raj, and he was able to amass a very fine collection of the medals awarded to the British Indian Army.

Times and interests change, however, and in recent years he has concentrated on the awards made by the Order of St John to volunteer ambulance men who took part in the South African War, 1899- 1902.

Peter's change of focus is described in the author's note in his book, Blackpool Division, St John Ambulance Brigade: The Early Years (1998):

'During my boyhood in Blackpool my curiosity was aroused by a memorial plaque on the wall of the foyer of the Town Hall [commemorating the services of Blackpool men in the South African War]. ... In 1995, while staying in my old home in Blackpool, I chanced to visit the Town Hall again, the memorial plaque was still on the wall, but now it had new meaning. I began to research into the activities of the local Division of the St John Ambulance Brigade ... ${ }^{\text {[7] }}$ 
The Most Venerable Order of the Hospital of St John of Jerusalem (commonly referred to as the Order of St John) traces its history back to a hospital established in Jerusalem in the 11th century CE. After many vicissitudes, the Order in England received a Royal Charter in May 1888, and Queen Victoria assented to become the Sovereign Head. In the meanwhile, in July 1877, the St John Ambulance Association had been formed, and in June 1887, the St John Ambulance Brigade was established.

As Peter Beighton notes, 'Within three weeks of the declaration of [the South African War] on October 11th, 1899, the [British] War Office had requested trained personnel' from the St John Ambulance

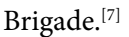

By February 1901, more than 1800 members of the Brigade had volunteered to serve in South Africa, roughly $20 \%$ of the total membership at that time. But almost 1000 of the volunteers came from a single district - District No. 4, in the north-west of England (which included the Blackpool Division). ${ }^{[7]}$

The Chapter-General of the Order of St John passed a resolution on 27 November 1900, approving the institution of the Medal for the South African War. The design was approved on 25 March 1902, when it was decided on grounds of cost to strike the medal in bronze, rather than in the more conventional silver.

A total of 1871 medals were issued, including 14 to members of the Brigade who went to China in the hospital ship, USS Maine, to take part in operations against the Boxers (Yihetuan Movement) ${ }^{[8]}$

Peter Beighton's original and ground-breaking research into the Medal for the South African War of the Order of St John has been exceptionally fruitful, resulting in the publication of a book, a thesis accepted for the degree of Master of Philosophy in History from the University of Lancaster, and six articles.
As his research has deepened, and research sources have become increasingly accessible, Peter has moved on from making the connection between medals and historical campaigns to painstaking studies of the lives of individual medal recipients, so that, for example, his book on the Blackpool Division contains 34 biographical notices.

\section{Envoi}

To those of us who know Peter Beighton, this aspect of his life's work is redolent with certain common themes that tell us so much about the man and his genius.

In the first place is his love and loyalty towards his Lancastrian origins, which colour not only his distinctive spoken English, but also his interest in genealogy and local history. And there is also the evidence of his passion, drive and energy. Of his fascination with the links between artefacts and their historical context. And - not least of his desire to share his research with the widest possible audience.

In his retirement, he continues to research his medals, making use of ever more digital resources to flesh out the life histories of servicemen, who would otherwise be in danger of being forgotten. With Peter Beighton, they are in safe hands.

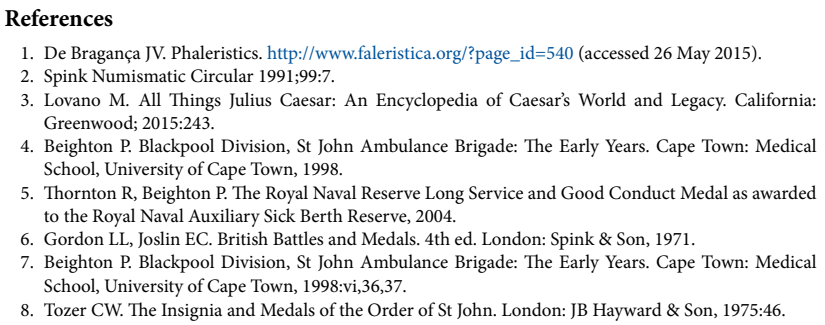

S Afr Med J 2016;106(6 Suppl 1):S19-S20. DOI:10.7196/SAMJ.2016.v106i6.10983 